\title{
Riverina high school students' views of biotechnology
}

\author{
Heather Cavanagh* \\ School of Biomedical Sciences \\ Charles Sturt University \\ Locked Bag 588, Wagga Wagga \\ NSW 2678, Australia \\ Tel: 61269332501 \\ Fax: 61269332587 \\ E-mail: hcavanagh@csu.edu.au \\ Jennie Hood \\ School of Biomedical Sciences \\ Charles Sturt University \\ Locked Bag 588, Wagga Wagga \\ NSW 2678, Australia \\ Tel: 61269332501 \\ Fax: 61269332587 \\ E-mail: jehood@csu.edu.au \\ Jenny Wilkinson \\ School of Biomedical Sciences \\ Charles Sturt University \\ Locked Bag 588, Wagga Wagga \\ NSW 2678, Australia \\ Tel: 61269332501 \\ Fax: 61269332587 \\ E-mail: jwilkinson@csu.edu.au
}

Keywords: biotechnology, education, science, secondary school.

A survey investigating the knowledge and perception of biotechnology by high school students living in the rural Riverina region of New South Wales, Australia, was undertaken. Data relating to the student' preferred and trusted information sources was also gathered. This study has demonstrated that at least two-thirds of students had a good knowledge of medical biotechnology issues, however, a significant proportion of the students did have concerns about the use and/or safety of biotechnology. Nearly $90 \%$ of the respondents would like further information on biotechnology. In agreement with other surveys, the students reported an apparent lack of trust in articles from the lay press (newspapers, television, radio) and yet still report that these media as the preferred information source. Interestingly, the high school students demonstrated a higher than national average acceptance of biotechnology.

Modern biotechnological processes are being continuously adapted for the production of crops, foods and pharmaceuticals which has lead to an increase in discussion about the benefits, or otherwise, of the technology. While it has been suggested that the attitude of the general public towards scientific developments in general are closely associated with trust in sources of information the role of increased scientific literacy and understanding of the technology remain unclear (Turney, 1996; Einsiedel, 2000). It has further been suggested that an increased understanding of biotechnology will assist people in making more informed decisions about this technology (Harms, 2002).

In line with this belief, high school curricula in many countries, including Australia, now include a biotechnology component (Harms, 2002). These modules typically include areas such as cloning, the use of genetic engineering in the production of novel crop species, production of pharmaceuticals in animals and the use of transgenic animals for human organ donation (Oka and Macer, 2000; Harms, 2002; NSW Department of Education). Discussion of the social and ethical issues associated with the use and development of biotechnology are also included by many high schools (Macer et al. 1994; Oka and Macer, 2000; Harms, 2002). It has been suggested that student opinions of biotechnology can be strongly influenced by the manner

*Corresponding author 
Table 1. Responses to questions relating to knowledge about biotechnology.

\begin{tabular}{|c|c|c|c|}
\hline \multirow[b]{2}{*}{ Do you agree that: } & \multicolumn{3}{|c|}{$\%$ of respondents $(n=87)$} \\
\hline & agree & disagree & unsure \\
\hline Ordinary tomatoes do not contain genes while genetically modified tomatoes do & 12.6 & 66.7 & 20.7 \\
\hline $\begin{array}{l}\text { The cloning of humans results in perfectly identical descendants (including physical } \\
\text { characteristics and personality) }\end{array}$ & 20.7 & 73.6 & 5.7 \\
\hline $\begin{array}{l}\text { If a person eats genetically modified fruits their own genes could be modified as a } \\
\text { result }\end{array}$ & 11.5 & 66.7 & 21.8 \\
\hline The yeast used to make beer contains living organisms & 75.9 & 8.0 & 16.1 \\
\hline More than half the genes of humans are identical to those of chimpanzees & 58.6 & 11.5 & 29.9 \\
\hline It is impossible to transfer animal genes to plants & 19.5 & 48.3 & 32.2 \\
\hline Criminal tendencies are mainly inherited genetically & 19.5 & 64.4 & 16.1 \\
\hline
\end{tabular}

in which this material is presented and the source of their information. Further, a general understanding of science and its interaction with society is thought to be more beneficial than detailed knowledge about scientific procedures (Turney, 1996; Macer et al. 1997; Einsiedel, 2000; Macer et al. 2000; Oka and Macer, 2000). How the introduction of these high school taught modules influence students perceptions of biotechnology remains unknown.

Numerous studies have been carried out to date examining the publics' perception and understanding of biotechnology. In Australia, however, these have tended to target the adult population rather than high school students. In this study we investigate the knowledge and perception of biotechnology by upper-level high school students living in a rural area of Australia. In addition, data relating to the students preferred and trusted information sources was also gathered.

\section{METHODS}

A questionnaire, based on those published by Biotechnology Australia (MBA, 2001; Myriad Research, 2001), was completed by upper-level high school students (years 10-12) attending a Biotechnology Innovation Festival in Wagga Wagga co-hosted by Charles Sturt University, Wagga Wagga City Council and Biotechnology Australia. Wagga Wagga is the largest centre (population 60,000) within the Riverina area of New South Wales (NSW) and has 5 high schools. The majority of the surrounding smaller townships have a single high school or one school shared between separate communities (NSW

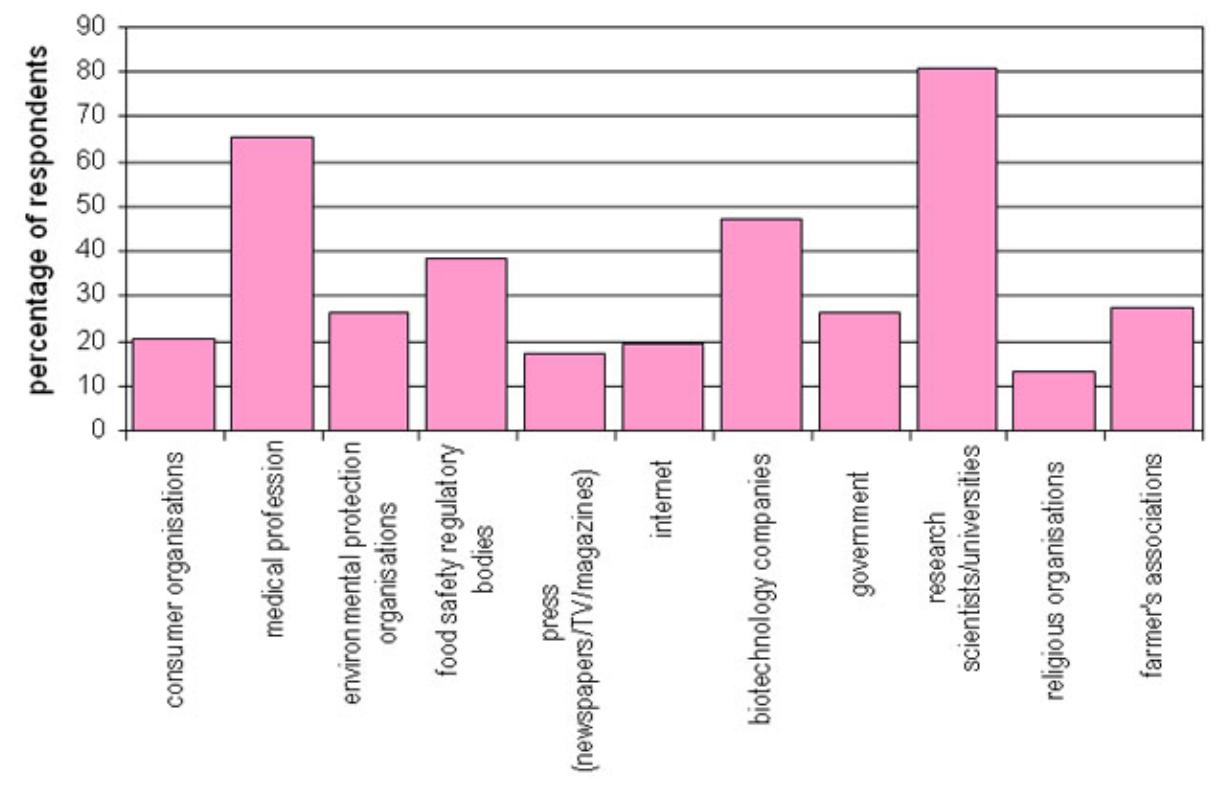

Figure 1. Percentage of students who trusted each of the listed items as sources of objective information about biotechnology. 
Table 2. Percentage of respondents indicating that they agree with various statements about biotechnology.

\begin{tabular}{|c|c|}
\hline Statements describing biotechnology & $\begin{array}{l}\% \text { respondents agreeing with statement } \\
(\mathrm{n}=87)\end{array}$ \\
\hline $\begin{array}{l}\text { Biotechnology is the genetic manipulation of living things for the } \\
\text { benefit of human health }\end{array}$ & $74.7 \%$ \\
\hline $\begin{array}{l}\text { Genetically modified crops will only benefit the lives of those people } \\
\text { who live in third world countries }\end{array}$ & $18.4 \%$ \\
\hline Biotechnology interferes with nature & $44.7 \%$ \\
\hline $\begin{array}{l}\text { Biotechnology will allow treatment and cure of genetic diseases } \\
\text { (human) }\end{array}$ & $72.4 \%$ \\
\hline Biotechnology will benefit human health & $63.2 \%$ \\
\hline Biotechnology will allow people to clone themselves & $29.9 \%$ \\
\hline $\begin{array}{l}\text { Biotechnology is only associated with GM (genetically modified) } \\
\text { crops such as canola and rice }\end{array}$ & $21.8 \%$ \\
\hline $\begin{array}{l}\text { Biotechnology produces new drugs each year which benefit human } \\
\text { health }\end{array}$ & $47.1 \%$ \\
\hline $\begin{array}{l}\text { Introducing genetically modified plants and animals into food for } \\
\text { human consumption will adversely affect human health }\end{array}$ & $23.0 \%$ \\
\hline $\begin{array}{l}\text { Biotechnology will have a major impact on the prevention, diagnosis } \\
\text { and treatment of human cancers }\end{array}$ & $57.5 \%$ \\
\hline
\end{tabular}

Department of Education). While 'school' attendance at the festival was voluntary, student attendance from an attending school was mandatory for students enrolled in the Biology HSC (Higher School Certificate). The questionnaire was completed as students entered the festival venue in May 2003. In addition to basic demographic data the questionnaire consisted of questions relating to knowledge of biotechnology, sources of information and views about usefulness and safety of various biotechnology related items. The project was approved by the Charles Sturt University Ethics in Human Research Committee.

The data was analysed using SPSS (Statistical Package for the Social Sciences, ver 10). Frequencies were calculated for each variable and comparisons made using Chi squared with differences deemed to be significant when $\mathrm{p}<0.05$. Correlations between variables were calculated using Pearsons correlation.

\section{RESULTS}

Eighty-seven completed questionnaires were received from festival attendees. The mean age of respondents was 16.8 years (standard deviation 0.8 years; range $15-18$ years) with $57.5 \%$ male and $42.5 \%$ female. Sixty one percent of respondents indicated that religion was not important to them with $22 \%$ indicating that religion was important and the remainder $(17 \%)$ that religion was very important. Responses to questions relating to knowledge of biotechnology are shown in Table 1. Most students answered six of the seven questions correctly, however the highest percentage of correct responses was $75.9 \%$ (use of yeast to make beer). The four questions relating to transfer of genes or genetically modified organisms elicited 'unsure' responses from greater than $20 \%$ of respondents.

The information sources students trusted for objective information about biotechnology are shown in Figure 1. Research scientists / universities were named as trusted sources of objective information most frequently $(80.7 \%$ of respondents) with medical professionals the second most frequently named $(65.1 \%)$. In contrast religious organizations $(13.3 \%)$, the press $(16.9 \%)$ and the Internet $(19.3 \%)$ were the least trusted sources of objective information.

Students were also asked to indicate which of 10 statements about biotechnology they agreed with (Table 2). Statements involving benefits to human health and crime solving (statements 1, 4, 5, 8 and 10) had the highest frequency of responses $(>50 \%)$. Statements relating to genetically modified crops being only of use in third world countries, human cloning and adverse effects on humans from 


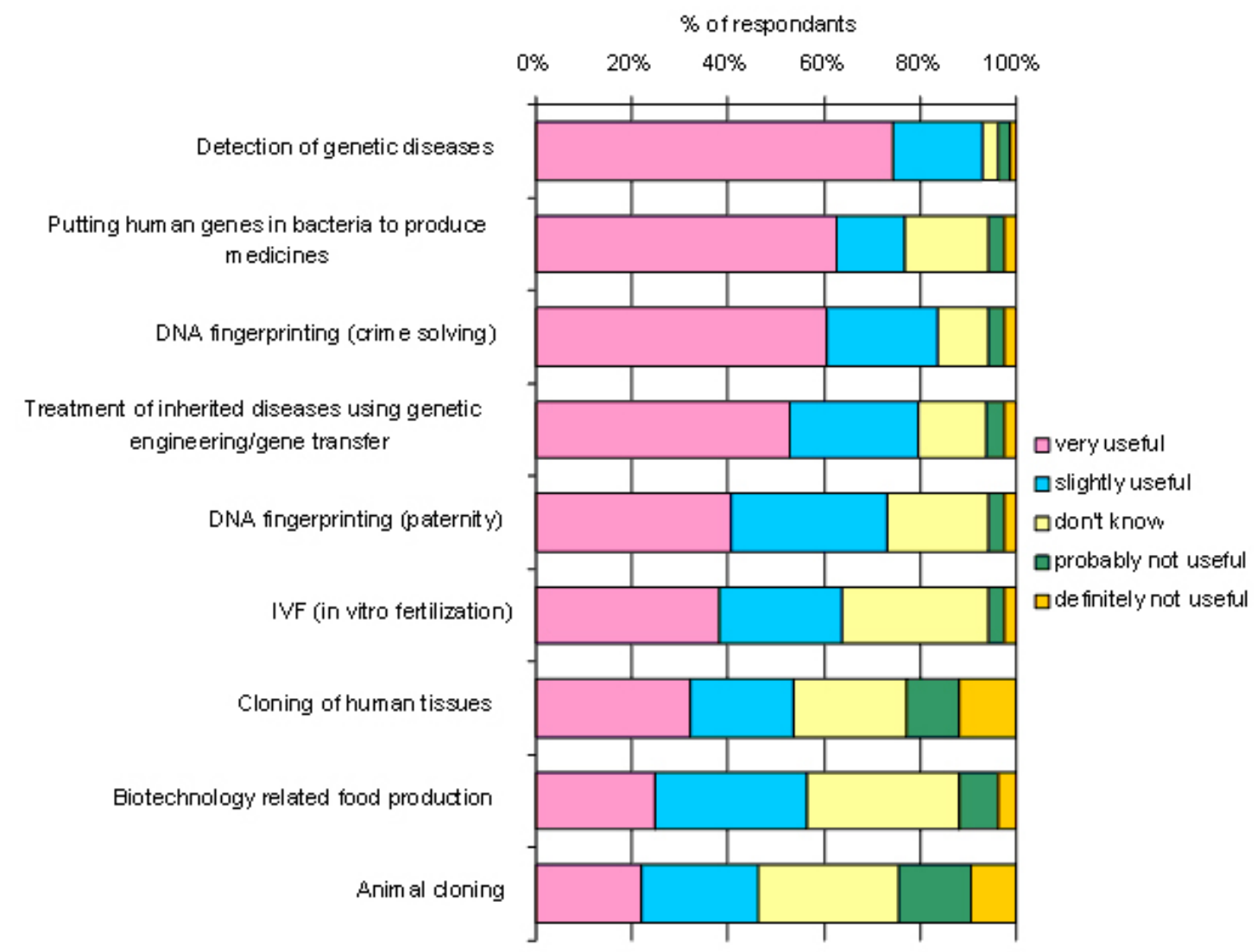

Figure 2. Graph showing the responses to questions about the usefulness of various applications of biotechnology.

genetically modified organisms had the lowest frequency of positive responses.

Most respondents felt that the benefits of genetic engineering would either definitely $(11.8 \%)$ or probably $(42.4 \%)$ outweigh the risks of this technology. However a large proportion (37.6\%) had mixed feelings on this issue. Only $3.5 \%$ of respondents thought that the benefits would definitely not (and $4.7 \%$ probably not) outweigh the risks of genetic engineering. Similarly most respondents thought that the recent advances in biotechnology would benefit them personally in the next 20 years $(10.5 \%$ definitely, $38.4 \%$ probably) with $9.3 \%$ indicating that the advances would probably not benefit them and 5.8\% that they would definitely not benefit them. The remainder $(36 \%)$ indicated that they did not know whether they would benefit from the advances. There was a significant, although weak, correlation between these two responses $(\mathrm{r}=0.2421, \mathrm{p}=$ $0.025)$.

The results for the responses to the questions relating to usefulness and safety of various uses of biotechnology are shown in Figure 2 and Figure 3, respectively. A summated score for both the indication of usefulness and safety of various uses of biotechnology was calculated. Each summated score has a maximum of 45: higher scores indicating either that the use was considered not useful or was considered dangerous. The mean score for usefulness was 17.5 (range 9-39) and for safety was 22.4 (range 9-34). There was a significant correlation between these two variables $(\mathrm{r}=0.649, \mathrm{p}<0.0001)$.

Most respondents (73.8\%) thought that the potential benefits of biotechnology, to the world as a whole, outweigh the risk. However $87.2 \%$ also thought that the general public is not given enough information about biotechnology and its potential role in human health. A similar percentage $(86.9 \%)$ wanted to know more about medical biotechnology with most $(63.6 \%)$ preferring to receive this information via local information sessions. Responses to other types of information sources were national television $(55.3 \%)$, articles in local or national newspaper (43.4\% each), local television (38.2\%) and local radio $(32.9 \%)$.

\section{DISCUSSION}

This report describes a survey administered to upper high school level students attending a Biotechnology Innovation festival in regional NSW, Australia. This area is primarily agricultural and is one of the few sites in NSW with approval to undertake small-scale field trials of genetically modified (GM) crop plants (Office of the Gene Technology Regulator). This study has demonstrated that at least two- 


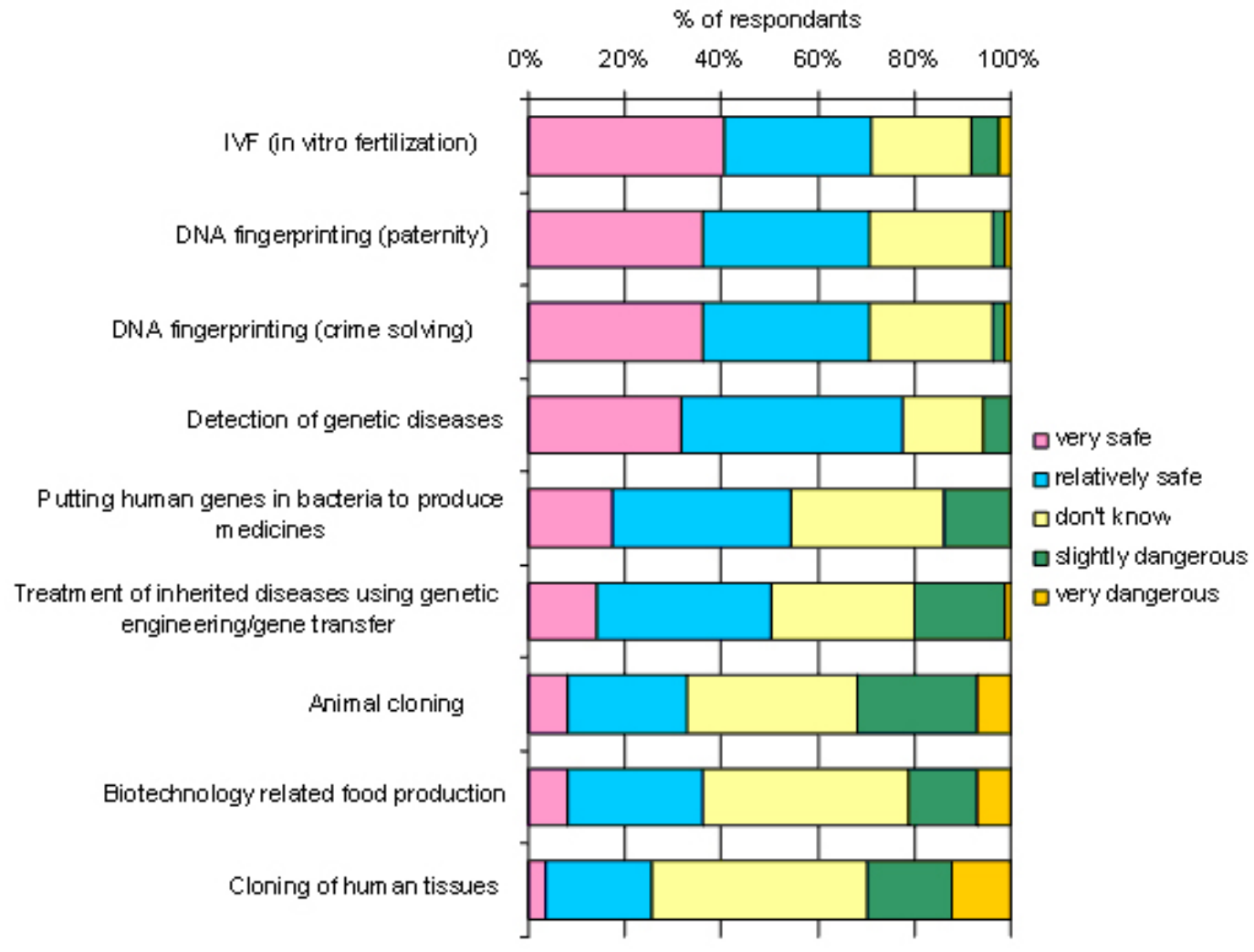

Figure 3. Graph showing the responses to questions about the safety of various applications of biotechnology.

thirds of students attending the Festival had good knowledge of medical biotechnology issues, however, a significant proportion of the students did have concerns about the use and/or safety of biotechnology. For example, $23 \%$ believed that eating genetically modified plants or crops would adversely affect human health (Table 2). Biotechnology was seen as something that is likely to benefit human health and recognised that it was not only associated with GM crops. Those areas related to food and cloning were considered least safe, while those related to crime, genetic testing, therapeutic production and IVF were considered the most safe. Perceptions of safely were also correlated with to those of usefulness, a trend which has been previously reported (Gaskell, 2000; Powell, 2000). It has been suggested that this link between safety and usefulness is directly related to communication and the availability of health and safety information rather than direct knowledge of the technology (Chess, 1998; Powell, 2000). It is interesting to note however, that although the majority of respondents in this study viewed biotechnology related food production as useful, they did not necessarily believe that it was safe or that it would not have an adverse effect on human health.

Unlike other Australian studies we have focused on high school students; however there are interesting parallels between the data from studies of the general adult population to that collected in this study. In three Australian surveys, $43 \%, 39 \%$ and $30 \%$ of respondents respectively identified research institutions such as CSIRO (Commonwealth Scientific and Industrial Research Organisation) as the most trusted source of information (Biotechnology Australia Survey: YCHW, 1999; Myriad Research, 2001; MBA, 2003). The Biotechnology Australia Report (YCHW, 1999) also found that $14 \%$ of respondents trusted scientists, $11 \%$ schools/universities and $11 \%$ consumer organisations as information sources. Similarly the majority $(80.7 \%)$ of the high school students in this study most trusted research scientists/universities as sources of objective information. Interestingly, this trust in the scientific community by Riverina high school students shows a significant increase over those found in national, adult population studies. This difference may be influenced by several factors such as the presence of a local University or high school students may simply be inherently more trusting of scientists than the general public. However as not all scientists or universities have the requisite expertise to comment on all or some biotechnology issues this trust may, in some circumstances, be misplaced.

It is possible that the data reported in this study was influenced by the fact that a university and the government body Biotechnology Australia ran the event, both of whom are known to have pro-biotechnology views. This combined with the extensive media coverage and probable classbased discussion about biotechnology related issues prior to Festival attendance might have resulted in the students being more aware and/or knowledgeable about the issues 
covered in the survey than student not exposed to these factors. Although the data presented in this study are not dissimilar to those reported in other Australian studies further research is required to fully assess the perception of biotechnology in school aged individuals.

In agreement with other Australian studies, student's trust in government sources and regulatory bodies was low (Macer et al. 2000), a finding consistent across the world. For example, a study in Japan reported similar low confidence in information sourced from government agencies but found that international regulatory bodies were the most trusted source of information with scientific organisations being the second most trusted source (Macer and $\mathrm{Ng}, 2000$ ).

Overall $87.2 \%$ of respondents felt that the public was not given enough information about biotechnology and its potential role in human health and $86.9 \%$ would like further information about medical biotechnology. The respondents in this study had a preference for receiving this information through local information sessions followed by television and newspapers. This is despite the finding that there was apparent distrust of the media as a source of objective information. Previous Australian studies have also noted that television and newspapers are the popular sources of information (Biotechnology Australia: MBA, 2001; Myriad Research, 2001; MBA, 2003). For example, the Biotechnology Australia Survey (MBA, 2003) cited television and newspapers as the most commonly used sources of information relating to biotechnology $(69 \%$ and $71 \%$ respectively), followed by radio $(31 \%)$, the Internet (24\%) and science/academic magazines (16\%).

Macer et al. (2000) found that 59\% of Australians viewed biotechnology as worthwhile; however $17 \%$ also reported having significant concerns about biotechnology. In the same study, $62 \%$ of Australians saw genetic engineering as worthwhile while $34 \%$ had concerns about this technology. These authors conclude that the general public will accept some products of genetic engineering provided that some benefit is seen. Similar percentages of respondents in both this study $(54.2 \%)$ and that conducted by Biotechnology Australia (2001a) felt that the benefits of genetic engineering would either definitely $(11.8 \%)$ or probably $(42.4 \%)$ outweigh the risks of this technology. The respondents in the current study indicated that the advances would probably not $(9.3 \%)$ or definitely not $(5.8 \%)$ benefit them (total 15.1\%) while the Biotechnology Australia study reported responses of $34 \%$ in 1999 falling to $26 \%$ in 2001 to this question in an adult population. Similarly, in 2000 it was reported that the majority of respondents in New Zealand and Thailand felt that the potential benefit of genetic engineering outweighed the risk while respondents in India and Japan felt the risks outweighed the benefit (Macer et al. 2000). Unlike Australia, it has been reported that support for biotechnology, and genetic engineering in particular, in Japan and Europe (with the exception of Spain and Austria) has declined in the period 1997 to 2000
(Macer and Ng, 2000; Hogan, 2003). The Euro-barometer 2002 survey reported that $43 \%$ of Europeans are optimistic that biotechnology will improve our way of life with $27 \%$ undecided (Euro-barometer, 2002).

Given that it is believed that public acceptance will play a major role in determining whether biotechnology developments such as animal generated organs for xenotransplant and stem cell technology continue to expand, it is vital that the scientific community continue to monitor the attitude of the public to biotechnology (Abelson and Hines, 1999; Einsiedel, 2000; McGloughlin, 2001). Indeed Von Wartburg and Liew (1999) state that an 'understanding of, and strength of belief in, the usefulness of a technology constitute the main factors governing its acceptance'. The reason for the significantly greater acceptance of biotechnology by the Riverina high school students surveyed in this study compared to that of the Australian general public is unknown. It is feasible that this is a 'local phenomenon' related to the interests of the students choosing to attend the festival. Whether the acceptance is true of Australian high school students in general, whether it is simply a reflection of high school students greater trust in the information sources used, or whether it is a reflection of increased understanding of biotechnology through school taught modules remains to be seen.

\section{REFERENCES}

ABELSON, P.A. and HINES, P.J. The plant revolution. Science, 1999, vol. 285, p. 367-368.

CHESS, C. Fearing fear: communication about agricultural biotechnology. AgBioForum, 1998, vol. 1,no. 1, p. 17-21. Also available from Internet: http://www.agbioforum.org/ v1n1/v1n1a05-chess.htm.

EINSIEDEL, E.F. Cloning and its discontents - A Canadian perspective. Nature Biotechnology, September 2000, vol. 18, p. 943-944.

European Commission, Eurobarometer Survey. Europeans and biotechnology. 2002. [cited 1 June 2004]. Available from Internet: http://europa.eu.int/comm/research /biosociety/public_understanding/eurobarometer_en .htm .

GASKELL, G. Agricultural biotechnology and public attitudes in the European union. AgBioForum, 2000, vol. 3, no. 2-3, p. 87-96. Also available from Internet: http://www.agbioforum.org/v3n23/v3n23a04-gaskell.htm.

HARMS, U. Biotechnology education in schools. Electronic Journal of Biotechnology [online]. 15 December 2002, vol. 15, no. 3 [cited 4 may 2004]. Available from Internet: http://www.ejbiotechnology.info/content/ vol5/3/teaching/01/. ISSN: 07173458.

HOGAN, S. Europeans and biotechnology survey of public perception. European Commission's Research Directorate- 
General Press Release. 2003. [cited 4 may 2004]. Available from Internet:http://www.eurekalert.org/pub_releases/200303/ecrd-ab032703.php.

MACER, D. and NG, M.A.C. Changing attitudes to biotechnology in Japan. Nature Biotechnology, September 2000, vol. 18, p. 945-947.

MACER, D.; AZARIAH, J. and SRINIVES, P. Attitudes to biotechnology in Asia. International Journal of Biotechnology, 2000, vol. 2, no. 4, p. 313-332.

MACER, D.; BEZAR, H.; HARMAN, N.; KAMADA, H. and MACER, N. Attitudes to biotechnology in New Zealand and Japan in 1997, with international comparisons. Eubios Journal of Asian and International Bioethics, 1997, vol. 7, p. 137-151.

MACER, D.; ASADA, Y.; AKIYAMA, S. and TSUZUKI, M. Bioethics in high schools in Australia, Japan and New Zealand. In: MACER, D.R.J. ed. Bioethics for the People by the People, Eubios Ethics Institute, 1994, p. 177-186.

MBA (Millward Brown Australia). Biotechnology Australia Biotechnology Public Awareness Survey Report. November 2003 [cited 10 May 2004]. Portable Document Format. Available from Internet: http://www.biotechnology.gov.au/ library/content_library/BA_MB2003_Final_Public.pdf.

MBA (Millward Brown Australia). Biotechnology Australia Biotechnology Public Awareness Survey Report. July 2001 [cited 10 May 2004]. Portable Document Format. Available from Internet: http://www.biotechnology.gov.au/ library/content_library/BA_Final_Report_Summary_31_Jul y_2001.pdf.

MCGLOUGHLIN, M. Public perceptions of agricultural biotechnology - a nonsocial science perspective. Medical Anthropology Quarterly, 2001, vol. 15, no. 1, p. 34-38.

MYRIAD RESEARCH. Biotechnology AustraliaResearch Report into Tasmanian Community Attitudes Towards Genetic Engineering and Genetic Manipulation Issues. May 2001 [cited 10 May 2004]. Available from Internet http://www.biotechnology.gov.au/content/controlfiles/displ ay_details.cfm?objectid=2205A44A-D36F-4CB5-

AE183BCB5DC30A18.

OKA, T. and MACER, D. Change in high school studentsw atitudes to biotechnology in reponse to teaching materials. Eubios Journal of Asian and International Bioethics, 2000, vol. 10, p. 174-178.

POWELL, D.A. Food safety and the consumer - perils of poor risk communication. Canadian Journal of Animal Science, 2000, vol. 80, no. 3, p. 393-404.

TURNEY, J. Public understanding of science. The Lancet, 1996, vol. 347, p. 1087-1090.
VON WARTBURG, W.P. and LIEW, J. Label this science science-free. Nature, 1999, vol. 16, no. 1, p. 1.

YCHW (Yann Campbell Hoare Wheeler). Biotechnology Australia Research Report into Public Attitudes Towards Biotechnology [online]. 1999 [cited 10 May 2004]. Portable Document Format. Available from Internet: http://www.biotechnology.gov.au/library/content_library/B A_pYCHW.pdf. 